\title{
APLIKASI E-COMMERCE SERAGAM OLAHRAGA PADA KOPERASI HASANKA BERBASIS WEB
}

\author{
Agung Prabowo, S.Kom., MMSI. \\ Program Studi Sistem Informasi \\ Sekolah Tinggi Manajemen Informatika dan Komputer (STMIK) \\ Palangka Raya Jln. G. Obos, No. 114, Palangka Raya, Kalimantan \\ Tengah
}

\begin{abstract}
ABSTRAK
Seiring dengan pesatnya perkembangan teknologi maka kebutuhan akan teknologi informasi juga sangat penting dalam segala aspek kehidupan, salah satunya melalui perkembangan teknologi internet yang merupakan salah satu media informasi yang berkembang saat ini dan terbukti sangat efektif. dan efisien dalam menyebarluaskan informasi yang dapat diakses oleh siapa saja, kapan saja dan dimana saja khususnya telah merambah bidang pemasaran dan penjualan (e-marketing) yang dapat menghubungkan antara penjual dan calon pembeli secara langsung tanpa dibatasi oleh ruang dan waktu. Saat ini media sosial telah menjadi kebutuhan dasar bagi sebagian orang, seseorang dapat berinteraksi dengan pengguna lain, atau mungkin dapat berbisnis dengan orang-orang dari berbagai kalangan. Tak heran jika banyak orang saat ini berbisnis melalui online. Namun demikian masih banyak instansi yang bergerak di bidang konveksi masih belum menggunakan internet dalam proses promosi atau transaksi sehingga usaha yang kurang berkembang salah satunya adalah Toko Koperasi Hasanka. Aplikasi ini dibangun Sistem Informasi Penjualan MySQL Berbasis Web pada Koperasi Hasanka Palangka Raya yang dibangun dengan menggunakan bahasa pemograman PHP, XML, HTML dan Database MySQL sebagai database dari aplikasi ini. Hasil skala likert adalah 705 atau 85,4\% terletak lebih dekat dengan interval Setuju (S), sehingga dapat diasumsikan bahwa program yang dibuat penulis telah memenuhi nilai guna yang baik.
\end{abstract}

Kata kunci: Aplikasi e-commerce, penjualan, saham, koperasi

\section{ABSTRACT}

Along with the rapid development of technology, the need for information technology is also very important in all aspects of life, one of which is through the development of internet technology, which is one of the growing media information today and has proven to be very effective and efficient in disseminating information that can be accessed by anyone, anytime and anywhere in particular has penetrated the field of marketing and sales (e-marketing) that can connect between sellers and prospective buyers directly without being limited by space and time. Nowadays social media has become a basic need for some people, someone can interact with other users, or maybe they can do business with people from various walks of life. No wonder so many people are currently doing business through online. However, there are still many agencies engaged in the field of convection still do not use the internet in the process of promotion or transactions so that underdeveloped businesses one of which is the Koperasi Hasanka Shop. This application was built MySQL Web-Based Sales Information System on Koperasi Hasanka Palangka Raya was built using the programming languages PHP, XML, HTML and MySQL Database as the database of this application. The result of the Likert scale is 705 or $85.4 \%$ located closer to the Agree (S) interval, so it can be assumed that the program that the author made has fulfilled a good value for use.

\section{Keyword : Aplikasi Ecommerce, penjualan, stok, koperas}

\section{PENDAHULUAN}

Seiring dengan perkembangan teknologi yang begitu pesat kebutuhan akan teknologi informasi pun sangat penting dalam segala aspek bidang kehidupan salah satunya adalah melalui perkembangan teknologi internet yang merupakan salah satu media informasi yang sedang berkembang saat ini dan telah terbukti sangat efektif dan efisien dalam penyebaran informasi yang dapat diakses oleh siapa saja, kapan saja dan dimana saja khususnya telah merambah dalam bidang pemasaran dan penjualan (e-marketing) yang dapat menghubungkan antara penjual dengan calon pembeli secara langsung tanpa dibatasi oleh ruang dan waktu.

Pada saat ini, Koperasi Hasanka belum menggunakan fasilitas e-commerce dalam proses promosi dan transaksi sehingga terkendala dalam proses penawaran produk kepada konsumen yang berada di luar kota. Selain itu, juga bisa mengakibatkan dampak yang berpengaruh kepada proses penjualan produk yang tidak produktif. Proses penjualan Koperasi Hasanka akan hanya dilakukan apabila terdapat konsumen yang datang ke toko tersebut, sedangkan banyak konsumen yang diluar 


\section{Jurnal Sains Komputer dan Teknologi Informasi $\mid$ Page \\ \begin{tabular}{ll|l} 
e - issn : 2655-7460. Volume 3 No.1, November 2020 & $123-127$
\end{tabular}}

kota tidak bisa datang atau tidak tahu keberadaan Koperasi Hasanka

Dari permasalahan tersebut dirancang dan dibangunlah sebuah sistem informasi penjualan barang yang berisikan data-data pembelian barang, stok barang, data-data penjualan barang serta laporanlaporan penjualan barang yang terjadi setiap harinya. Dari sistem ini diharapkan dapat menyelesaikan masalah laporan data penjualan barang dengan cepat dan kapan saja jika dibutuhkan dan hasil dari proses pengolahan data ini pun lebih akurat dibanding jika dilakukan proses pengolahan data dengan sistem konvensional. E-Commerce itu sendiri adalah sistem perdagangan dengan menggunakan perangkat mobile yang dapat membantu konsumen dalam proses penjualan. Dengan adanya sistem ini, diharapkan Koperasi Hasanka dapat memasarkan barang jualannya secara online sehingga konsumen bisa melihat dan memesan produk tanpa harus mendatangi secara langsung toko tersebut.

Berdasarkan paparan permasalahan pada paragraf sebelumnya maka penulis mengangkat sebuah ide penelitian dengan judul "Aplikasi $\boldsymbol{E}$ - commerce Seragam Olahraga Pada Koperasi Hasanka Berbasis Web". Dalam aplikasi ini yang diterapkan penulis yaitu Framework Bootsrap. Bootsrap adalah suatu sistem user interface berbasis HTML 5 yang diakses untuk membuat situs web dan aplikasi yang dapat diakses oleh semua perangkat smartphone, tablet dan desktop.

\section{TINJAUAN PUSTAKA}

Ayu Kartika Sari (2017) Membuat sistem informasi penjualan pada toko kue putri palangkaraya berbasis web,yang berfungsi untuk memenuhi kebutuhan sistem yang ada dibidang penjualan,sistem ini nantinya berguna untuk memepermudah dalam proses pemesanan dan penjualan.

Metty Mustika Sari (2015) Dengan adanya aplikasi e-commerce agen zoya berbasis web dapat memberi kemudahan kepada agen untuk mendapatkan informasi serta melakukan proses belanja secara cepat tanpa harus datang kegudang.

Aulan Hari (2014) Dengan adanya Aplikasi web e-commerce peralatan tenis meja pada toko combinasi sport palangkaraya dapat memberikan kemudahan konsumen dalam mendapatkan informasi yang dicarinya serta mempermudah masyarakat untuk melakukan transaksi tanpa harus pergi keberbagai toko olahraga tenis meja.

Karyono (2013) menyatakan dengan adanya aplikasi $e$ - commerce sparepart mobil Yogyakarta menggunakan PHP dan MySQL dapat memberikan kemudahan pelanggan dalam mencari informasi terbaru mengenai sparepart yang dipasarkan.

Perbedaan penelitian terdahulu dibandingkan dengan penelitian ini adalah penelitian yang dikembangkan dari beberapa penelitian sebelumnya dengan penelitian yang dibuat penulis memiliki persamaan yaitu dalam pengembangan e-commerce berbasis web yang dapat diakses melalui smartphone dan $P C$, namun berbeda dalam bentuk studi kasus informasi yang disajikan dan pengelolaan yang lebih komplek yaitu mengelola jenis ekspedisi dan biaya.

\section{METODE PENELITIAN}

Metode Pengumpulan Data

Metode Observasi

Metode Observasi merupakan metode untuk melaksanakan pengamatan dengan pencatatan data secara langsung, pengenalan kondisi dan situasi yang ada pada lingkungan Koperasi Hasanka Palangka Raya.

Metode Wawancara

Selain Observasi, metode lain yang digunakan adalah metode Interview atau wawancara dalam pengumpulan data. Jenis wawancara adalah wawancara pribadi. Wawancara ini dilakukan oleh penulis dengan seorang narasumber dengan memberikan beberapa pertanyaan terkait penelitian yang dilakukan kepada pihak Koperasi Hasanka Palangka Raya untuk melengkapi data yang digunakan untuk penelitian dan hal-hal yang dianggap dianggap perlu yang berkaitan dengan materi yang dibahas.

Metode Dokumentasi

Selain wawancara, penelitian ini juga menggunakan metode dokumentasi dalam pengumpulan data. Dalam pengumpulan data, penulis melakukan dokumentasi berbentuk tulisan dan dokumentasi berbentuk gambar kepada pihak sekolah untuk melengkapi data yang digunakan untuk penelitian dan hal-hal yang dianggap perlu yang berkaitan dengan materi yang dibahas.

Metode kepustakaan

Adalah metode pengumpulan data dengan mempelajari beberapa buku yang berhubungan dengan topik, dokumen-dokumen yang berhubungan dengan permasalahan yang sedang dokumentasi.

Metode Pengembangan Sistem

Penelitian ini menggunakan model Waterfall. Model ini merupakan sebuah pendekatan terhadap pengembangan perangkat lunak yang sistematik, dengan beberapa tahapan yaitu definisi persyaratan, perancangan sistem dan perangkat lunak, implementasi dan pengujian unit, integrasi dan pengujian sistem dan Operasi dan pemeliharan.

Tahapan-tahapan komponen pemodelan waterfall adalah sebagai berikut: 


\section{Agung Prabowo. Aplikasi E-Commerce Seragam Olahraga Pada Koperasi

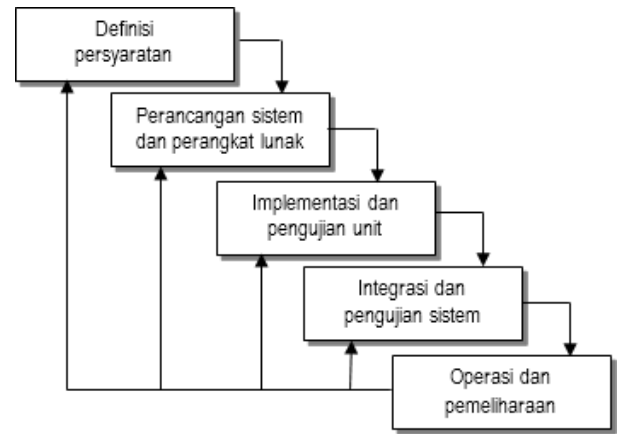

Gambar 1. Waterfall

\section{HASIL DAN PEMBAHASAN}

\section{A. Rancangan Sistem}

Berdasarkan tahapan pada pemodelan sistem yang penulis gunakan, maka penulis akan menjelaskan tentang Unifield Modelling Language(UML). Pada tahapan ini akan menguraikan dalam beberapa diagram yaitu use case diagram.

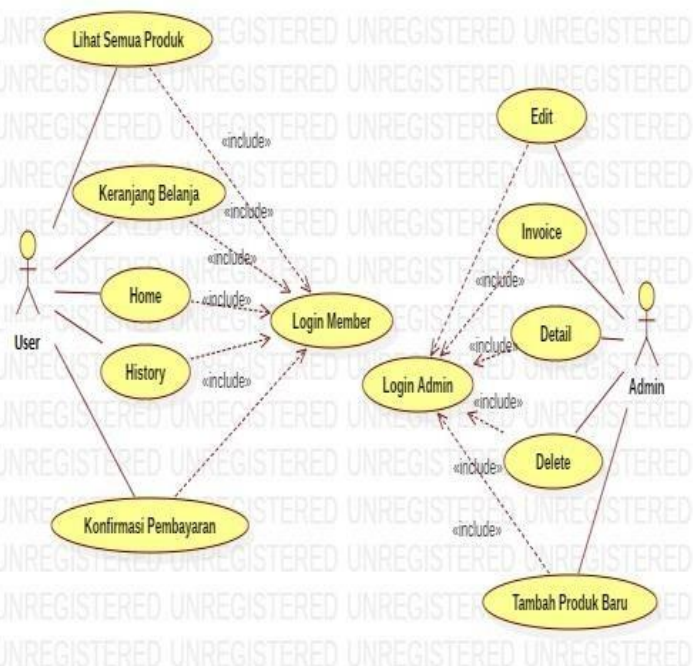

Gambar 2 Use Case Diagram

Use case diagram pada Gambar 2 menjelaskan proses yang dilakukan oleh user dalam hal ini adalah pelanggan dimana dalam proses transaksi didahului dengan proses login yang username dan passwordnya lalu dapat melakukan proses transaksi yang diawali dengan memilih produk, lalu menentukan ekspedisi, proses transfer dan upload bukti transfer yang kemudian dilakukan proses verifikasi admin lalu barang akan dikirim. Pada halaman admin, semua proses pengelolaan data dapat dilakukan diantaranya kelola barang dan kategorinya, transaksi pembayaran, berita dan informasi serta laporan transaksi.

Implementasi dan Pengujian Sistem

Pada tahap ini implementasi terhadap program yang dibangun dapat bekerja sebagaimana diharapkan yang meliputi uji coba sistem, manual program, dan pemeliharaan, sehingga program yang dibuat dapat diketahui kekurangan dan dapat dimengerti dengan baik serta diketahui cara penggunaannya oleh pemakai.

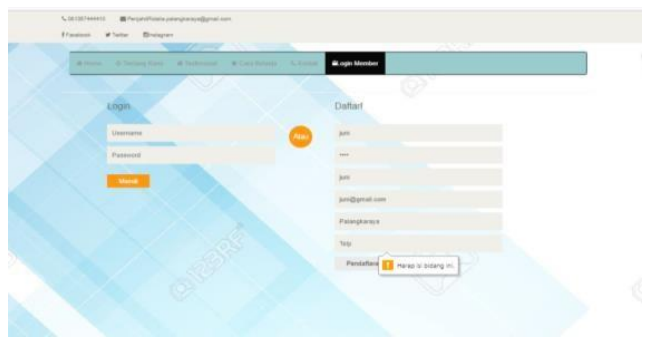

Gambar 3. Login

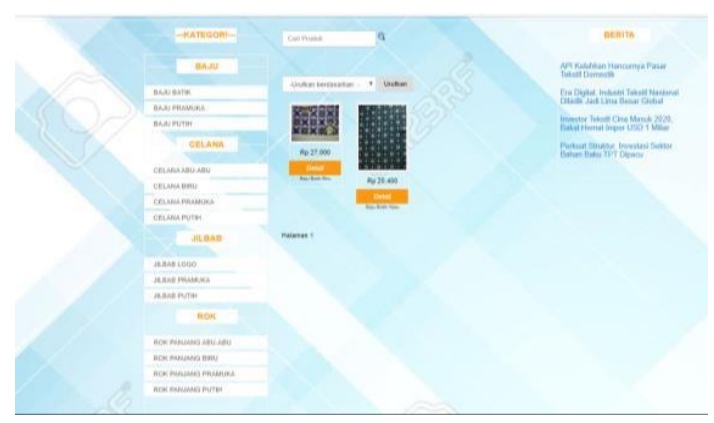

Gambar 4. Halaman Utama

Selanjutnya, sistem ini diuji menggunakan metode blackbox testing, yang hasilnya dapat dilihat pada tabel dibawah ini :

\begin{tabular}{|c|c|l|l|}
\hline No. & $\begin{array}{c}\text { Skenario } \\
\text { Pengujian }\end{array}$ & \multicolumn{1}{|c|}{$\begin{array}{c}\text { Hasil yg di } \\
\text { harapkan }\end{array}$} & $\begin{array}{c}\text { Kes } \\
\text { imp } \\
\text { ulan }\end{array}$ \\
\hline 1. & $\begin{array}{l}\text { Menampil } \\
\text { kan (jika } \\
\text { sesuai) }\end{array}$ & $\begin{array}{l}\text { User memasukkan } \\
\text { link pada browser, } \\
\text { kemudian } \\
\text { melakukan login } \\
\text { setelah sukses maka } \\
\text { akan tampil menu } \\
\text { utama }\end{array}$ & $\begin{array}{l}\text { Sesua } \\
\text { i }\end{array}$ \\
\hline 2. & $\begin{array}{l}\text { Menampil } \\
\text { kan (jika } \\
\text { sesuai) }\end{array}$ & $\begin{array}{l}\text { User menekan menu } \\
\text { login, tampil } \\
\text { halaman login. } \\
\text { Kemudian pengguna } \\
\text { menekan tombol } \\
\text { tambah user, setelah } \\
\text { itu pengguna dapat } \\
\text { mengisi semua field } \\
\text { Pendaftaran user lalu } \\
\text { menekan tombol } \\
\text { simpan. }\end{array}$ & Sesuai \\
\hline 3. & Menampil & admin menekan & \\
\hline
\end{tabular}




\section{Jurnal Sains Komputer dan Teknologi Informasi $\mid$ Page \\ e - issn : 2655-7460. Volume 3 No.1, November $2020 \quad 123-127$}

\begin{tabular}{|c|c|c|c|}
\hline & $\begin{array}{l}\text { kan (jika } \\
\text { sesuai) }\end{array}$ & $\begin{array}{l}\text { menu data produk } \\
\text { baru, tampil halaman } \\
\text { produk. Kemudian } \\
\text { admin menekan } \\
\text { tombol tambah } \\
\text { produk, setelah itu } \\
\text { admin dapat mengisi } \\
\text { semua field produk } \\
\text { lalu menekan tombol } \\
\text { simpan. }\end{array}$ & Sesuai \\
\hline 4. & $\begin{array}{l}\text { Menampil } \\
\text { kan (jika } \\
\text { sesuai) }\end{array}$ & $\begin{array}{l}\text { User menekan menu } \\
\text { Pengolahan Data } \\
\text { ongkir, Data ongkir } \\
\text { beserta status } \\
\text { loginnya itu sudah } \\
\text { seleksi atau pun } \\
\text { yang belum di } \\
\text { seleksi untuk bisa } \\
\text { masuk ke halaman } \\
\text { admin. }\end{array}$ & Sesuai \\
\hline 5. & $\begin{array}{l}\text { Menampil } \\
\text { kan (jika } \\
\text { sesuai) }\end{array}$ & $\begin{array}{l}\text { User menekan menu } \\
\text { cart silahkan untuk } \\
\text { lanjut dan berbelanja } \\
\text { lagi, kemudian } \\
\text { tampil transaksi, } \\
\text { dimana user } \\
\text { melakukan } \\
\text { konfirmasi } \\
\text { pembayaran }\end{array}$ & Sesuai \\
\hline
\end{tabular}

\section{KESIMPULAN DAN SARAN}

Berdasarkan pembahasan pada bab-bab sebelumnya maka diambil beberapa kesimpulan, yaitu:

1. Aplikasi Ecommerce Seragam Olahraga Pada Koperasi Hasanka Berbasis Web ini telah berhasil dibangun. Pembangunan aplikasi menggunakan metode waterfall dengan melakukan definisi persyaratan, perancangan system dan perangkat lunak, implementasi dan pengujian unit, integrasi dan pengujian system dan Operasi dan pemeliharan.

2. Tahapan Analisis Sistem dalam tahap ini yang akan dilakukan penulis adalah merancang pemodelan system dan desain interface program agar alur dari proses program tersebut jelas. Untuk pemodelan system penulis menggunakan pemodelan sistem Unified Modelling Language (UML) yaitu: Activity Diagram, Use Case Diagram, Class Diagram dan Sequence Diagram.

3. Aplikasi ini dibangun MySQL Sistem Informasi Penjualan Berbasis Web pada Penjahit Koperasi Hasanka Palangka Raya ini dibangun dengan menggunakan dengan bahasa pemprograman
PHP, XML, HTML dan Database MySQL sebagai basis data dari aplikasi ini.

4. Hasil skala likert adalah 705 atau $85,4 \%$ terletak lebih dekat interval Setuju (S), sehingga dapat diasumsikan bahwa program yang penulis buat telah memenuhi nilai yang baik untuk digunakan.

Untuk implementasi dan pengembangan di masa yang akan datang, diusulkan saran-saran sebagai berikut :

1. Penulis mengharapkan untuk pengembangan aplikasi mobile selanjutnya, diharapkan juga dapat dijalankan diberbagai platform, seperti Blackberry OS, IOS, dan lain sebagainya, sehingga dapat menjangkau semua sistem operasi smartphone yang digunakan oleh user.Selain itu juga, diharapkan tampilan untuk aplikasi Mobile, lebih interaktif.

2. Penulis mengharapkan aplikasi selanjutnya dapat mengetahui posisi barang atau tracker pengiriman produk dengan fitur google maps

3. Sistem ini hendaknya dapat dipergunakan oleh user yang memahami sistem komputerisasi, sehingga proses pengelolaan datanya dapat dilakukan dengan baik.

4. Untuk mencegah rusaknya atau hilangnya data dalam file database, sebaiknya dilakukan back up secara berkala dan scan terhadap virus yang merusak.

\section{DAFTAR PUSTAKA}

Abdulloh, Rohi. 2015. Web Programing is Easy, PT Elex Media Komputindo. Jakarta.

Arief, M. Rudyanto. 2011. Pemrograman Web Dinamis Menggunakan PHP \& MySQL, Andi, Yogyakarta.

Hari, Aulan. 2014. Web E-Commerce Peralatan Olahraga Tenis Meja Pada Toko Combinasi Sport Palangkaraya, STMIK Palangkaraya, Palangkaraya Jogiyanto. 2012. Analisis dan Desain Sistem Informasi. Yogyakarta, Andi, Yogyakarta.

Kadir, Abdul. 2009. Memahami Sistem Informasi. Andi, Yogyakarta

Karyono. 2013. Rancang Bangun E- Commerce Penjualan Sparepart Mobil,STMIK AMIKOM Yogyakarta, Yogyakarta.

Loudon.2014. Membangun Bisnis E-Commerce yang Handal, PT Transmedia, Jakarta.

Lucas, Henry. 2013. Entity Relationship dan Normalisasi, Elex Media Komputindo, Jakarta.

Nugroho, Adi. 2011. Rekayasa Perangkat Lunak Menggunakan UML dan Java, Andi, Yogyakarta.

Pressmen, Roger, S. 2010. Rekayasa Perangkat Lunak, Andi, Yogyakarta.

Sudaryono, dkk. 2011. Theory and application of IT research, ANDI, Yogyakarta.

Sugiyono. 2011.Metode Penelitian Kuantitatif, Kualitatif, dan R\&D.Alfabeta. Bandung. 
Sutabari, Tata, 2014, Prinsip Manajemen Sistem Informasi, Analisis Sistem, Grahallmu, Yogyakarta.

Sutedjo, Budi. 2012. Perancangan Dan Pembangunan Sistem Informasi, Andi, Yogyakarta.

Wahyono. Teguh. 2014. Sistem Informasi: Konsep Dasar, Analisis, Desain Dan Implentasi, Graha Ilmu, Yogyakarta

Ridha. 2011. Perdagangan, Balai Pustaka, Jakarta

Santoso, Budi. 2005. Perancangan Dan

Pembangunan Sistem Informasi, Andi. Yogyakarta.
Sari, Ayu, Kartika. 2017. Sistem Informasi Penjualan Pada Toko Kue Putri Palangkaraya Berbasis Web, STMIK Palangkaraya

Sari, Mustika, Metty. 2015. Rancang Bangun Aplikasi E-Commerce Agen Zoya Berbasis Web, STMIK Palangkaraya, Palangka Raya.

Sommerville, Ian. 2013. Software engineering Rekayasa Perangkat Lunak. Erlangga. 